University of Nebraska - Lincoln

DigitalCommons@University of Nebraska - Lincoln

Publications from USDA-ARS / UNL Faculty

U.S. Department of Agriculture: Agricultural

Research Service, Lincoln, Nebraska

2013

\title{
Seasonal temperature and precipitation effects on cow-calf production in northern mixed-grass prairie
}

\author{
Justin L. Reeves \\ USDA-Agricultural Research Service Rangeland Resources Research Unit, Justin.Reeves@ars.usda.gov \\ Justin D. Derner \\ USDA-ARS, Justin.Derner@ars.usda.gov \\ Matt A. Sanderson \\ USDA-Agricultural Research Service, Northern Great Plains Research Laboratory \\ Mark K. Petersen \\ USDA-Agricultural Research Service, Fort Keogh Livestockand Range Research Laboratory \\ Lance T. Vermeire \\ USDA-Agricultural Research Service, Fort Keogh Livestockand Range Research Laboratory, \\ lance.vermeire@ars.usda.gov
}

See next page for additional authors

Follow this and additional works at: https://digitalcommons.unl.edu/usdaarsfacpub

Reeves, Justin L.; Derner, Justin D.; Sanderson, Matt A.; Petersen, Mark K.; Vermeire, Lance T.; Hendrickson, John R.; and Kronberg, Scott L., "Seasonal temperature and precipitation effects on cow-calf production in northern mixed-grass prairie" (2013). Publications from USDA-ARS / UNL Faculty. 1467.

https://digitalcommons.unl.edu/usdaarsfacpub/1467

This Article is brought to you for free and open access by the U.S. Department of Agriculture: Agricultural Research Service, Lincoln, Nebraska at DigitalCommons@University of Nebraska - Lincoln. It has been accepted for inclusion in Publications from USDA-ARS / UNL Faculty by an authorized administrator of DigitalCommons@University of Nebraska - Lincoln. 


\section{Authors}

Justin L. Reeves, Justin D. Derner, Matt A. Sanderson, Mark K. Petersen, Lance T. Vermeire, John R. Hendrickson, and Scott L. Kronberg 


\title{
Seasonal temperature and precipitation effects on cow-calf production in northern mixed-grass prairie ${ }^{\text {is }}$
}

\author{
Justin L. Reeves ${ }^{\text {a,* }}$, Justin D. Derner ${ }^{\text {a }}$, Matt A. Sanderson ${ }^{b}$, Mark K. Petersen ${ }^{\text {, }}$, \\ Lance T. Vermeire ${ }^{\mathrm{c}}$, John R. Hendrickson ${ }^{\mathrm{b}}$, Scott L. Kronberg ${ }^{\mathrm{b}}$ \\ a USDA-Agricultural Research Service Rangeland Resources Research Unit, High Plains Grasslands Research Station, \\ 8408 Hildreth Road, Cheyenne, WY 82009, USA \\ ${ }^{\mathrm{b}}$ USDA-Agricultural Research Service, Northern Great Plains Research Laboratory, Mandan, ND 58554, USA \\ ${ }^{\mathrm{c}}$ USDA-Agricultural Research Service, Fort Keogh Livestock and Range Research Laboratory, Miles City, MT 59301, USA
}

\section{A R T I C L E I N F O}

\section{Article history:}

Received 15 February 2013

Received in revised form

22 April 2013

Accepted 24 April 2013

\section{Keywords:}

Climate variability

Decision support tools

Grazing management

Model averaging

Semiarid rangeland

Long-term Agro-Ecosystem Research (LTAR)

\begin{abstract}
A B S T R A C T
Quantifying the effects of seasonal temperature and precipitation on cow-calf production on rangelands is challenging, as few long-term ( $>20$ yrs) studies have been reported. However, an understanding of how seasonal weather inconsistency affects beef production is needed for beef producers to better manage their herds on native rangelands to minimize enterprise risk with respect to climatic variability. Cow-calf beef production data collected at the USDA-ARS High Plains Grasslands Research Station near Cheyenne, WY, USA from 1975 to 2012 were tested using model averaging for effects of spring (April-June) and summer (July-September) temperature and precipitation, as well as prior winter (October-March) and prior growing season (April-September) precipitation on beef production. Two breeds were used at different times during the study period (Herefords from 1975 to 2001 and a Red Angus $\times$ Charolais $\times$ Salers cross from 2003 to 2012; there was no grazing in 2002) and examined separately to test for differential effects of seasonal weather by breed. Herefords were more sensitive to seasonal weather patterns than the crossbreds, with Hereford pair total beef production showing the largest effect sizes and Hereford cows showing the highest $R^{2}$ value (0.66) among models. Wet springs and wet winters particularly increased Hereford beef production in this northern mixed-grass prairie, whereas beef production from the crossbreds did not show any weather effect patterns. The model structure used maximizes utility of these data to be built into decision support tools to help ranchers optimize stocking rates and minimize enterprise risk in advance of the grazing season.
\end{abstract}

Published by Elsevier B.V.

\section{Introduction}

To accommodate food demand for a growing world population, livestock production will need to increase by
200 million tonnes/yr by 2050 (FAO, 2011). Cow-calf production will therefore need to increase both in quantity and efficiency. Several factors are known to influence cow-calf production. These include genetic background

\footnotetext{
The U.S. Department of Agriculture (USDA) prohibits discrimination in all its programs and activities on the basis of race, color, national origin, age, disability, and where applicable, sex, marital status, family status, parental status, religion, sexual orientation, genetic information, political beliefs, reprisal, or because all or part of an individual's income is derived from any public assistance program. (Not all prohibited bases apply to all programs.) Persons with disabilities who require alternative means for communication of program information (Braille, large print, audiotape, etc.) should contact USDA's TARGET Center at (202) 720-2600 (voice and TDD). To file a complaint of discrimination, write to UDSA, Director, Office of Civil Rights, 1400 Independence Avenue, S.W., Washington, D.C. 20250-9414, or call (800) 795-3272 (voice) or (202) 720-6382 (TDD). USDA is an equal opportunity provider and employer.

* Corresponding author. Tel.: +1 307772 2433x103; fax: +1 3076376124.

E-mail address: Justin.Reeves@ars.usda.gov (J.L. Reeves).
} 
of cows and calves (Davis et al., 1994; Grings et al., 1996), cow body composition (Houghton et al., 1990), calving season and weaning date (Grings et al., 2005), stocking rate (Gillen and Sims, 2002; Kothmann et al., 1971), winter diet supplementation (Patterson et al., 1999), and parasite control (Stromberg et al., 1997). Other aspects such as pasture plant composition have also been used to examine cow-calf production and suggest optimal stocking rates (Hart et al., 1988). Though these multiple factors have been documented, other important, but understudied, factors such as seasonal weather variability may also influence cow-calf production on rangelands. A better understanding of seasonal weather effects on beef production from rangelands will ideally translate into reduced enterprise risk and more efficient beef production through increased predictive capacity to match management decisions with expected seasonal weather.

The 30 million ha of northern mixed-grass prairie represents the largest area of rangeland in the United States (Holechek et al., 1998). Within the northern mixedgrass prairie of Wyoming, USA, 91\% of ranching operations (the primary land use in this ecosystem) are cow-calf producers (Kachergis et al., 2013). As such, elucidating the effects of seasonal temperature and precipitation on cow-calf production would enhance management of these operations. Though prior work has shown that spring (April+May+June) precipitation increases forage production in northern mixed-grass prairie (Derner and Hart, 2007), and that forage production positively influences cow-calf production (Andales et al., 2005), more work is needed to better understand the direct effects of seasonal weather conditions on cow-calf performance.

There are few published, long-term datasets that would make it possible to elucidate seasonal weather effects on cattle (Briske et al., 2011). Of the few long-term cattle production studies that have been reported, only Derner et al. (2008), MacNeil and Vermeire (2012), and Reeves et al. (in press) directly examined effects of seasonal weather patterns on cattle weight gains. Reeves et al. (in press) showed that yearling steers were differentially impacted by seasonal weather patterns at different stocking rates, with steer production at heavy stocking rates being more sensitive to seasonal weather. At heavier stocking rates, cool, wet springs and warm, wet summers were optimal for yearling steer production in a $C_{3}-C_{4}$ northern mixed-grass prairie. Similarly, Derner et al. (2008) reported that spring (April+May+June) precipitation increased yearling steer weight gains in a $C_{3}-C_{4}$ northern mixed-grass prairie. Further, MacNeil and Vermeire (2012) found that longer, cooler growing seasons were beneficial for Hereford calf weight gains in a $\mathrm{C}_{3}$-dominated northern mixed-grass prairie. Extending our understanding of seasonal weather effects of cow-calf body weight gains will help develop decision support tools that will allow ranchers to become better managers of their rangeland resources in the face of an increasingly variable climate.

Previous modeling efforts have shown both direct and indirect effects of climate change and variability on cattle production (e.g., Andales et al., 2005; Hanson et al., 1993; Mader et al., 2009; Ritten et al., 2010; Torell et al., 2010).
None of these models, however, were built using data that directly linked cattle weight gain responses to temperature and precipitation. For instance, Andales et al. (2005), using the Great Plains Framework for Agricultural Resource Management (GPFARM; Shaffer et al., 2000) decision support system, determined that forage production was a good predictor of cow-calf production. However, including direct effects of environmental conditions such as seasonal temperature and precipitation on beef production may increase prediction accuracy of GPFARM (and other models), especially since environmental conditions can directly impact livestock production (Ames, 1980).

Cow-calf production data from 1975 to 2012 collected at the USDA-Agricultural Research Service (ARS) High Plains Grasslands Research Station (HPGRS) near Cheyenne, WY (see site description below) were used here to test three hypotheses. First, as a result of our similar yearling steer study (Reeves et al., in press), we hypothesized that cool, wet springs and warm, wet summers would increase cow-calf production (kg beef produced/ ha) through seasonally optimal conditions for increased forage production in this mixed $C_{3}-C_{4}$ grass system (Derner and Hart, 2007; Williams III, 1974). Second, we hypothesized that cow production would be more sensitive than calf production to seasonal temperature and precipitation variation because cows could withstand body weight loss in support of maintaining milk production for calf production in times of poor seasonal weather conditions that limit forage quality and quantity (Chigaru and Topps, 1981). Finally, we hypothesized that breeds would respond differently to seasonal weather variability (both Herefords and crossbred Red Angus $\times$ Charolais $\times$ Salers were used at different times during study period; see below). We expected that the larger crossbred cows would produce more milk than smaller Herefords (Cartwright, 1979; Melton et al., 1967), which would translate into enhanced moderation of effects attributed to seasonal weather conditions.

\section{Materials and methods}

\subsection{Site description}

This experiment was performed on northern mixedgrass prairie at HPGRS, approximately $7 \mathrm{~km}$ northwest of Cheyenne, Wyoming $\left(41^{\circ} 11^{\prime} \mathrm{N}, 104^{\circ} 53^{\prime} \mathrm{W}\right)$. Mean annual precipitation (132 yr) is $381 \mathrm{~mm}$, peaking in May (mean annual precipitation was $408 \mathrm{~mm}$ during study years). Soils are well-drained, coarse, and largely comprised of Albinas, Ascalon and Altvan loams (mixed mesic Aridic Argiustolls), and Cascajo gravelly loam (mixed mesic Aridic Calciorthid; Stevenson et al., 1984). The primary ecological site is Loamy (Site ID is R067AY122WY). Grasses are the primary vegetation at HPGRS. Perennial cool-season $\left(C_{3}\right)$ graminoids include western wheatgrass (Pascopyrum smithii [Rydb.] Á. Löve), needle-and-thread (Hesperostipa comata [Trin. \& Rupr.] Barkworth), prairie junegrass (Koeleria macrantha [Ledeb.] J.A. Schultes), and needleleaf sedge (Carex duriuscula C.A. Mey). Blue grama (Bouteloua gracilis [H.B.K.] Lag. ex Griffiths) is the primary perennial warm-season $\left(\mathrm{C}_{4}\right)$ grass. Scarlet globemallow (Sphaeralcea 
coccinea [Nutt.] Rydb.) is the primary forb, and fringed sage (Artemisia frigida Willd.) is the primary sub-shrub. Cool-season grasses decrease, whereas forbs and the warm-season grass blue grama increase over time under heavy stocking rates in this northern mixed-grass prairie (Manley et al., 1997).

\subsection{Grazing experiment}

The grazing experiment was initiated in 1975 and data have been collected each year to present (except 2002; see below). One primary goal of this grazing experiment was to maintain a season-long (early June-early October), continuous, moderate ( 20-30 Animal Unit Days/ha [AUD]), stocking rate each year. Throughout the study, however, stocking rates were adjusted to match forage availability in an effort to ensure animal welfare. Specific experimental pastures varied over the years due to pasture configurations and various concurrent experiments. For the below models, we selected only one pasture per year to include in the analyses when data were collected from multiple pastures in the same year. The selected pasture most closely represented a moderate stocking rate and the same pasture was selected from year-to-year when possible (groups of pastures of the same size [ha] in Table 1 indicate data taken from same pastures across years). Cow--calf pairs did not graze

Table 1

Grazing dates and stocking rates by breed $(\mathrm{H}=$ Hereford; $\mathrm{C}=$ Red Angus $\times$ Charolais $\times$ Salers crossbred) for cow-calf data included in seasonal weather models. All animals in pasture were used in calculating stocking rates. Animal unit equivalents were calculated by dividing mid-season combined weights of cow-calf pairs by $1000 \mathrm{~kg}$. Cattle were not grazed in 2002 because of drought. Data were excluded for 1985, 1991, and 1994 due to substantial experimental differences in these years (see Grazing experiment Section 2.2 above).

\begin{tabular}{|c|c|c|c|c|c|c|c|c|c|}
\hline Year & Breed & $\begin{array}{l}\text { Date } \\
\text { on }\end{array}$ & $\begin{array}{l}\text { Date } \\
\text { off }\end{array}$ & Days & $\begin{array}{l}\text { Pasture size } \\
\text { (ha) }\end{array}$ & $\begin{array}{l}\text { No. pairs; no. dry cows } \\
\text { or heifers }\end{array}$ & $\begin{array}{l}\text { Animal unit } \\
\text { equivalent }\end{array}$ & $\begin{array}{l}\text { Animal } \\
\text { units }\end{array}$ & $\begin{array}{l}\text { Stocking rate } \\
\text { (AUD/ha) }\end{array}$ \\
\hline 1975 & $\mathrm{H}$ & 18-Jun & 11-Sep & 85 & 192.0 & $21 ; 4$ & 1.33 & 31.9 & 14.1 \\
\hline 1976 & $\mathrm{H}$ & 15-Jun & 21-Sep & 98 & 192.0 & $26 ; 1$ & 1.41 & 37.7 & 19.2 \\
\hline 1977 & $\mathrm{H}$ & $\begin{array}{l}24- \\
\text { Jun }\end{array}$ & 20-Sep & 88 & 192.0 & $32 ; 1$ & 1.38 & 45.1 & 20.7 \\
\hline 1978 & $\mathrm{H}$ & 13-Jun & 27-Sep & 106 & 191.4 & $29 ; 5$ & 1.34 & 43.8 & 24.3 \\
\hline 1979 & $\mathrm{H}$ & $\begin{array}{l}20- \\
\text { Jun }\end{array}$ & 25-Sep & 97 & 183.3 & 27 & 1.39 & 37.6 & 19.9 \\
\hline 1980 & $\mathrm{H}$ & 13-Jun & 17-Sep & 96 & 191.4 & $28 ; 2$ & 1.33 & 39.2 & 19.7 \\
\hline 1981 & $\mathrm{H}$ & $\begin{array}{l}26- \\
\text { Jun }\end{array}$ & 22-Sep & 88 & 191.4 & 25 & 1.49 & 37.4 & 17.2 \\
\hline 1982 & $\mathrm{H}$ & 8-Jul & 28-Sep & 82 & 191.4 & 33 & 1.47 & 48.4 & 20.8 \\
\hline 1983 & $\mathrm{H}$ & 9-Jun & 28-Sep & 111 & 191.4 & $31 ; 1$ & 1.30 & 41.3 & 24.0 \\
\hline 1984 & $\mathrm{H}$ & 6-Jul & 26-Sep & 82 & 191.4 & 40 & 1.49 & 59.6 & 25.5 \\
\hline 1986 & $\mathrm{H}$ & $\begin{array}{l}27- \\
\text { Jun }\end{array}$ & 3-Sep & 68 & 56.1 & 13 & 1.30 & 17.0 & 20.6 \\
\hline 1987 & $\mathrm{H}$ & 10-Jun & 14-Oct & 126 & 56.1 & $11 ; 2$ & 1.35 & 16.8 & 37.8 \\
\hline 1988 & $\mathrm{H}$ & 10-Jun & 28-Sep & 110 & 48.6 & $6 ; 6$ & 1.46 & 14.8 & 33.4 \\
\hline 1989 & $\mathrm{H}$ & $\begin{array}{l}26- \\
\text { Jun }\end{array}$ & $\begin{array}{l}31- \\
\text { Aug }\end{array}$ & 66 & 48.6 & $6 ; 2$ & 1.46 & 10.8 & 14.6 \\
\hline 1990 & $\mathrm{H}$ & 13-Jun & 4-Oct & 113 & 48.6 & $7 ; 3$ & 1.50 & 13.5 & 31.5 \\
\hline 1992 & $\mathrm{H}$ & 17-Jun & 6-Oct & 111 & 78.3 & 17 & 1.48 & 25.2 & 35.7 \\
\hline 1993 & $\mathrm{H}$ & $\begin{array}{l}\text { 29- } \\
\text { Jun }\end{array}$ & 21-Oct & 114 & 78.3 & 17 & 1.44 & 24.5 & 35.7 \\
\hline 1995 & $\mathrm{H}$ & Jun & $25-\mathrm{Oct}$ & 120 & 78.3 & $21 ; 1$ & 1.38 & 30.0 & 45.9 \\
\hline 1996 & $\mathrm{H}$ & 4-Jun & 24-Sep & 112 & 78.3 & 8 & 1.47 & 11.8 & 16.9 \\
\hline 1997 & $\mathrm{H}$ & 2-Jun & 11-Sep & 101 & 78.3 & 7 & 1.54 & 10.8 & 13.9 \\
\hline 1998 & $\mathrm{H}$ & $\begin{array}{l}22- \\
\text { Jun }\end{array}$ & 17-Sep & 87 & 78.3 & 7 & 1.75 & 12.3 & 13.6 \\
\hline 1999 & $\mathrm{H}$ & 17-Jun & 16-Sep & 91 & 78.3 & 8 & 1.58 & 12.7 & 14.7 \\
\hline 2000 & $\mathrm{H}$ & 13-Jun & 15-Sep & 94 & 78.3 & 5 & 1.62 & 8.1 & 9.7 \\
\hline 2001 & $\mathrm{H}$ & 12-Jun & 7-Sep & 87 & 78.3 & 7 & 1.47 & 10.3 & 11.4 \\
\hline Mean & - & - & - & 97.2 & - & - & - & - & 22.5 \\
\hline SD & - & - & - & 15.6 & - & - & - & - & 9.5 \\
\hline 2003 & $\mathrm{M}$ & 10-Jun & $14-O c t$ & 126 & 75.0 & 9 & 1.84 & 16.6 & 27.8 \\
\hline 2004 & $\mathrm{M}$ & 8-Jun & 14-Oct & 128 & 75.0 & 9 & 1.90 & 17.1 & 29.1 \\
\hline 2005 & $\mathrm{M}$ & 6-Jun & 13-Oct & 129 & 75.0 & 8 & 1.94 & 15.5 & 26.7 \\
\hline 2006 & $\mathrm{M}$ & 6-Jun & $12-$-Oct & 128 & 75.0 & 9 & 1.93 & 17.3 & 29.6 \\
\hline 2007 & $\mathrm{M}$ & 5-Jun & $11-O c t$ & 128 & 75.0 & 9 & 1.81 & 16.3 & 27.9 \\
\hline 2008 & $\mathrm{M}$ & 3-Jun & 9-Oct & 128 & 75.0 & 9 & 1.71 & 15.4 & 26.3 \\
\hline 2009 & $\mathrm{M}$ & 4-Jun & 19-Oct & 137 & 75.0 & 9 & 1.76 & 15.8 & 28.9 \\
\hline 2010 & $\mathrm{M}$ & 2-Jun & 7-Oct & 127 & 75.0 & 9 & 1.81 & 16.3 & 27.6 \\
\hline 2011 & $\mathrm{M}$ & 1-Jun & 7-Oct & 128 & 75.0 & 9 & 1.91 & 17.2 & 29.3 \\
\hline 2012 & $\mathrm{M}$ & 5-Jun & 10-Oct & 127 & 75.0 & 9 & 1.83 & 16.5 & 28.0 \\
\hline Mean & - & - & - & 128.6 & - & - & - & - & 28.1 \\
\hline SD & - & - & - & 3.1 & - & - & - & - & 1.1 \\
\hline
\end{tabular}


experimental pastures in 2002 due to drought. Data for 1985 were removed because of poor spring weather conditions and a corresponding abnormally late end of the grazing season. Data from 1991 were removed because pasture configurations changed and pairs had grazing access to previously ungrazed areas, thereby violating our assumptions and inclusion criteria. Finally, data from 1994 were removed due to poor wintering of animals and winter weight loss, which allowed for compensatory weight gains and therefore abnormally high beef production. See Table 1 for grazing dates and stocking rates for each year. When calculating stocking rates, animal unit equivalents were calculated by dividing the mid-season cow-calf combined weights by $1000 \mathrm{~kg}$. All animals in the pasture (whether study animals or not) were used in calculating stocking rates.

The cow-calf pairs used in this experiment from 1975 to 2001 were Herefords provided by the University of Wyoming, Laramie, WY, USA. From 2003 to present, Red Angus $\times$ Charolais $\times$ Salers crossbreed cows (bred from Red Angus sire and Charolais $\times$ Salers dams) were used and provided by a private rancher. Each cow and calf was weighed before and after each grazing season. Prior to each body weight measurement, cattle were held overnight without food or water. All experimental procedures were undertaken with the approval and oversight of the HPGRS Animal Care and Use Committee. Total beef production $(\mathrm{kg} / \mathrm{ha})$ was calculated by dividing the sum of seasonal weight gains for cows, calves, and pairs by the number of total hectares.

\subsection{Statistical analyses and model fitting}

Wilcoxon tests were used to test for differences between breeds for entry weights and beef production (kg/ha) for cows, calves, and pairs. This non-parametric method was selected because of the differences in sample size of years between breeds.

For our livestock-weather models, we used model averaging methodology in JMP 10.0.0 (SAS Institute Inc., 2012; as in Reeves et al. (in press)) to test for effects of within-season and seasonal lag of temperature and precipitation on cow-calf weight gains. This method averages model coefficients with respect to sample size corrected Akaike Information Criterion (AICc) weights (SAS Institute Inc., 2012; http://www.jmp.com/support/help/The_Mode 1_Averaging_Option.shtml). Model averaging allows for fitting and averaging multiple competing models, thereby accounting for model uncertainty and selection procedure bias. This prevents selection of a poor model (Wang et al., 2009). Model averaging produces models with excellent predictive abilities (SAS Institute Inc., 2012) that often are more accurate than "best-model" strategies (Burnham and Anderson 2004). See Burnham and Anderson (2004) and Wang et al. (2009) for model averaging reviews.

In our model averaging structure, we used a maximum of nine terms (our models had nine total variables; see below) for individual models and an AICc cutoff weight of 0.95 for selection of models to be averaged (see SAS Institute Inc., 2012). Model averaging is an informationtheoretic approach, and as such, trends must be interpreted and inferred from results tables. Information- theoretic approaches such as this can provide many benefits over traditional null hypothesis testing and interpretation of $P$-values (Anderson et al., 2000).

We selected our model structure based on parsimony and a priori hypotheses (rather than "data dredging") to avoid spurious effects and overfitting of the data (Anderson et al., 2001). Our model structure was also selected to be consistent with climatic data and forecasts available to ranchers to maximize utility for decision support tools (Derner et al., 2012). For example, the National Atmospheric and Oceanic Administration (NOAA) provides free, webbased, seasonal, three-month weather forecasts for any three month period up to a year in advance (see http:// www.nws.noaa.gov/predictions.php). As such, our modeled current season weather variables included three-month clusters.

Cow-calf production models had nine parameters. First, to account for likely genetic differences in animal size and production across study years, animal (or pair total) entry weights were used in the models. Entry weights were selected to be used here, for example, because although Hereford cow entry weights and exit weights were closely related to each other (exit weight $=149.99+0.78 \times$ entry weight; $R^{2}=0.84 ; P<0.0001$; data not shown), the entry weights were more closely related to beef production than were the exit weights ( $R^{2}=0.47$ vs. 0.24 respectively; data not shown). Hereford cow entry weights increased linearly over the course of the study (entry weight $=-5714.62$ $+3.11 \times \mathrm{yr} ; R^{2}=0.37 ; P=0.0016$; data not shown), and because they had a linear relationship to beef production (Hereford beef production $=34.37-0.06 \times$ entry weight; $R^{2}=0.47 ; P=0.0002$; data not shown), entry weights were appropriate to include as a liner predictor in the multiple linear regression models performed here. Further, given that entry weights could not have been confounded by seasonal length or weather patterns as exit weights would have been, entry weights were the best available option to account for genetic differences across study years given the available data.

Beyond entry weights, and following Reeves et al. (in press), we included total precipitation ( $\mathrm{mm}$ ) and average (of average) temperature values $\left({ }^{\circ} \mathrm{C}\right.$; mid-point between maximum and minimum temperatures at HPGRS weather stations or archived NOAA weather data when HPGRS weather station data were unavailable). Total precipitation and average temperature data were calculated for both spring (April-June) and summer (July-September) of the current grazing season. An interaction term of precipitation $\times$ temperature was also included for these spring and summer clusters in case the effects of temperature and precipitation were not additive. Because previous precipitation and forage production can affect current year forage production (Oesterheld et al., 2001), we also included prior growing season (April-September) and prior fall/winter (October-March) precipitation, but not temperature.

We modeled total beef production ( $\mathrm{kg} / \mathrm{ha}$ ) separately for cows, calves, and cow-calf pairs to allow for comparison of seasonal weather effects on each animal classification. We modeled cows and calves separately to test our hypothesis that cows would be more sensitive to weather 
variability, and also the combined pair since beef producers often consider pairs as a single unit. Because initial models and analyses showed differences in production between breeds, we also modeled each breed separately for comparison purposes and to account for difference between breeds. Models were constructed under a hypothesis testing framework (Anderson et al., 2001) to maximize both biological meaning and management tool utility (Derner et al., 2012) rather than to provide the highest fit, most complicated and intricate ecological model possible.

The presented model coefficients were not standardized, as the aim of this study was use these models for predictive purposes (i.e., inclusion in decision support tools), as well as to compare results to other similar long-term datasets. Thus, because temperature $\left({ }^{\circ} \mathrm{C}\right)$ and precipitation $(\mathrm{mm})$ values are on different scales, the resulting model averaged values coefficients for these two types of variables are not directly comparable to each other. Within temperatures and precipitation values, however, larger coefficient estimates more reasonably indicate a larger effect on cow, calf, or pair production. Parameter estimates which were larger than their respective standard errors were considered to be robust (important) predictors
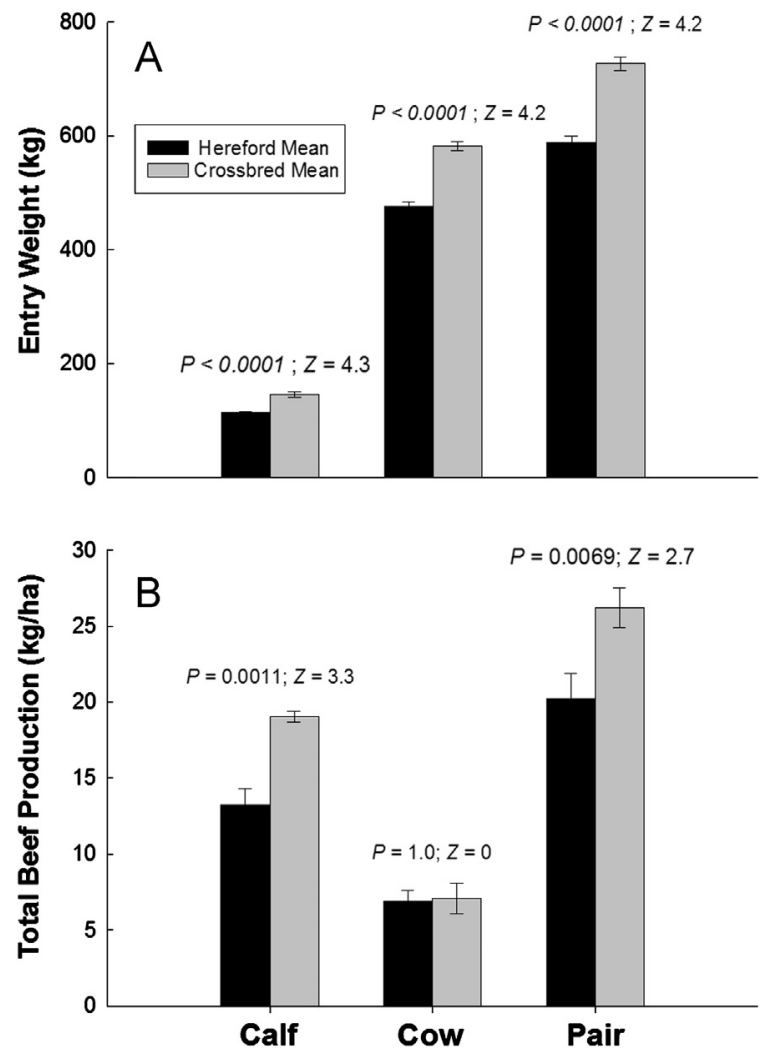

Fig. 1. Comparisons between breeds for cow, calf, and pair entry weights (kg; panel $[\mathrm{A}]$ ), along with total beef production (kg/ha; panel [B]). Bars represent mean $\pm 1 \mathrm{SE}$. $P$-values and $Z$ values are results from Wilcoxon tests. Herefords were used from 1975 to 2001 and the Red Angus $\times$ Charloais $\times$ Salers crossbreds were used from 2003 to 2012 . Herefords had a lower mean stocking than crossbreds (Table 1 ), which likely contributed to differences in beef production. of cattle production, as standard errors indicate tendency of the averaged regression coefficients toward zero (SAS Institute Inc., 2012).

\section{Results}

Wilcoxon tests indicated differences between breeds for initial cow and calf body weights, with the crossbreds being larger than the Herefords (Fig. 1A). Calf and pair average yearly total beef production were likewise greater for the crossbreds, with similar average cow yearly total beef production between breeds (Fig. 1B). These breed differences justified modeling seasonal weather effects on breeds separately for comparison purposes.

For both the Hereford (1975-2001) and Red Angu$\mathrm{s} \times$ Charolais $\times$ Salers (2003-2012) datasets, though a potential confound existed because of the different sets of years and therefore different weather values, similar variability existed in the weather parameters examined (Table 2). Though the crossbred dataset spanned fewer years than the Hereford dataset, at least a three-fold spread existed between extreme years for all of the seasonal precipitation variables (Table 2). There also existed a $5.6^{\circ} \mathrm{C}$ range in an average spring temperature, with a $6.7^{\circ} \mathrm{C}$ range in summer average temperature (Table 2). Similarly, in the longer Hereford dataset, at least a three-fold spread existed for all of the precipitation variables. A $5.3^{\circ} \mathrm{C}$ and $4.6{ }^{\circ} \mathrm{C}$ range existed for spring and summer average temperatures, respectively (Table 2).

Hereford calves had larger parameter estimates than cows in many instances (Table 3). Overall, however, Hereford pair total production showed the largest parameter estimates, with Hereford cows showing the highest $R^{2}$ value (Table 3 ). The unstandardized coefficients make it somewhat difficult to directly compare coefficient sizes across animal types, however. Across Hereford cow, calf, and pair totals, spring (April-June) precipitation was an important determinant of beef production, having relatively large parameter estimates that were robust to respective standard errors. For Hereford calves and pairs, prior winter (October-March) precipitation also showed large parameter estimates that were robust to standard errors. Also for Hereford calves and pairs, the robust summer (July-September) precipitation $\times$ temperature interaction terms may indicate that the importance of summer precipitation increases as summer temperatures are higher. It should be noted that interaction terms in the context of model averaging can be difficult to interpret, however, and need more research (Dochtermann and Jenkins, 2011). All remaining weather parameter estimates for Hereford cows, calves, and pairs were small and/or not robust to standard errors. Entry weight had a robust, negative effect on Hereford cow and pair production, indicating that initially larger cows (and pairs) tended to gain less throughout the grazing season. Compared to the Herefords, the crossbreds had much smaller parameter estimates, none of which were robust to standard errors (Table 4), indicating that this mixed breed may be less sensitive to seasonal temperature and precipitation variation than Herefords. 
Table 2

Summary of seasonal weather variables with year of extreme values across study years for Hereford (1975-2001) and crossbred Red Angus $\times$ Charolais $\times$ Salers (2003-2012) cattle.

\begin{tabular}{|c|c|c|c|c|c|c|}
\hline & \multicolumn{4}{|c|}{ Precipitation (mm) } & \multicolumn{2}{|c|}{ Avg. temperature $\left({ }^{\circ} \mathrm{C}\right)$} \\
\hline & Prior Apr-Sep & Prior Oct-Mar & Apr-Jun & Jul-Sep & Apr-Jun & Jul-Sep \\
\hline \multicolumn{7}{|c|}{ Hereford } \\
\hline Mean & 301.6 & 111.2 & 185.6 & 129.7 & 9.9 & 17.2 \\
\hline SD & 98.5 & 43.6 & 66.6 & 49.7 & 1.2 & 1.1 \\
\hline Low & 168.7 (1975) & 50.1 (1977) & $64.2(2000)$ & 53.6 (1998) & $7.2(1983)$ & 15.2 (1987) \\
\hline High & 506.8 (1996) & $197.6(1980)$ & 342.0 (1983) & 263.7 (1997) & 12.5 (1977) & 19.8 (1995) \\
\hline \multicolumn{7}{|c|}{ Crossbred } \\
\hline Mean & 278.8 & 83.0 & 171.7 & 118.3 & 10.3 & 17.2 \\
\hline SD & 92.1 & 43.4 & 73.1 & 57.1 & 1.7 & 1.9 \\
\hline Low & $120(2003)$ & 29.2 (2007) & 71.4 (2006) & $55.1(2010)$ & 7.7 (2003) & $12.6(2003)$ \\
\hline High & 396.5 (2012) & $159.5(2010)$ & $263.2(2005)$ & $214.9(2008)$ & 13.3 (2012) & $19.3(2010)$ \\
\hline
\end{tabular}

Table 3

Model averaged estimates of seasonal weather variable and entry weight effects on Hereford cow, calf, and pair beef production (kg/ha). Sample sizes ( $n$ ) in column headers indicate the number of models that were averaged (weighted) for each analysis. Bolded values show coefficients for which the modelaveraged estimates were greater than standard error, indicating importance of that variable. Note that reported coefficients are unstandardized, as results are to be used for predictive purposes and comparison to other datasets.

\begin{tabular}{|c|c|c|c|c|c|c|}
\hline \multirow[t]{2}{*}{ Variable } & \multicolumn{2}{|c|}{$\operatorname{Cow}(n=81)$} & \multicolumn{2}{|c|}{ Calf $(n=158)$} & \multicolumn{2}{|c|}{ Pair $(n=157)$} \\
\hline & Estimate & Std. error & Estimate & Std. error & Estimate & Std. error \\
\hline Intercept & 25.030 & - & 0.421 & - & 19.733 & - \\
\hline Animal (or pair) entry weight & -0.048 & 0.012 & 0.011 & 0.032 & -0.028 & 0.019 \\
\hline Apr-Jun precipitation & 0.019 & 0.007 & 0.033 & 0.013 & 0.053 & 0.019 \\
\hline Apr-Jun avg. temperature & 0.107 & 0.212 & 0.265 & 0.407 & 0.456 & 0.620 \\
\hline (Apr-Jun precipitation $) \times($ Apr-Jun avg. temperature $)$ & 0.000 & 0.002 & 0.003 & 0.005 & 0.002 & 0.006 \\
\hline Jul-Sep precipitation & 0.001 & 0.004 & 0.003 & 0.008 & 0.004 & 0.010 \\
\hline Jul-Sep avg. temperature & 0.003 & 0.168 & -0.015 & 0.305 & 0.008 & 0.430 \\
\hline (Jul-Sep precipitation $) \times($ Jul-Sep avg. temp $)$ & 0.011 & 0.009 & 0.042 & 0.019 & 0.062 & 0.027 \\
\hline Prior Apr-Sep precipitation & 0.000 & 0.002 & 0.000 & 0.003 & 0.000 & 0.005 \\
\hline Prior Oct-Mar precipitation & 0.001 & 0.005 & 0.029 & 0.016 & 0.025 & 0.020 \\
\hline Coefficient of determination $\left(R^{2}\right)$ & 0.66 & & 0.56 & & 0.62 & \\
\hline
\end{tabular}

\section{Discussion}

Our first hypothesis that cool, wet springs and warm, wet summers would positively influence cow-calf production was generally unsupported. Though increased spring precipitation was beneficial for Hereford production, there were no robust spring temperature effects, and the spring temperature coefficients were positive (Table 3 ). Cool spring temperatures can increase cool-season $\left(C_{3}\right)$ grass production (Williams III, 1974), and thus perhaps cow-calf production as hypothesized. However, cool springs were not beneficial here, perhaps because slightly warmer springs approached optimal temperatures for milk production (Johnson, 1965) and overall animal comfort and growth (Ames, 1980). These results differed from Reeves et al. (in press) who showed increased yearling steer production during cool, wet springs at moderate stocking rates; however, the lack of robust spring temperature effects here (Table 3 ) was perhaps a result of slightly warmer springs not being warm enough to affect $C_{3}$ grass production (Sage and Kubien 2007). Because Reeves et al. (in press) used yearling steers and different experimental methods in different pastures at HPGRS, it becomes somewhat problematic to directly compare results.
Our second hypothesis that cows would be most sensitive to seasonal weather variability was also unsupported to some extent, as both Hereford calves and pairs showed higher coefficient estimates than cows (Table 3 ). However, the Hereford cows did show the highest $R^{2}$ values (even with the fewest robust coefficients), so it becomes difficult to judge which set of animals was most sensitive to seasonal weather. Poor nutrition can decrease milk (and therefore calf) production (Corah et al. 1975), which could have resulted here from low forage availability due to reduced spring precipitation (Derner and Hart, 2007). Relatively poor nutrition through corresponding reductions in diet selection and quality may have contributed to Hereford cows being unable to moderate weather effects for calves during times of detrimental weather conditions. Since pair totals were most sensitive to weather, we hypothesize that the effects of both individual animals being combined increased detectability of effects by the models.

In contrast to our first two hypotheses, our third hypothesis that Herefords would be more sensitive to seasonal weather variability than the crossbreds was supported. The Red Angus $\times$ Charolais $\times$ Salers individual animals and pairs had small, non-robust parameter 
Table 4

Model averaged estimates of seasonal weather variable and entry weight effects on Red Angus $\times$ Charolais $\times$ Salers cow, calf, and pair beef production $(\mathrm{kg} / \mathrm{ha}$ ). Sample sizes $(n)$ in column headers indicate the number of models that were averaged (weighted) for each analysis. No variables were robust to standard error. Note that reported coefficients are unstandardized, as results are to be used for predictive purposes and comparison to other datasets.

\begin{tabular}{|c|c|c|c|c|c|c|}
\hline \multirow[t]{2}{*}{ Variable } & \multicolumn{2}{|c|}{ Cow $(n=36)$} & \multicolumn{2}{|c|}{ Calf $(n=35)$} & \multicolumn{2}{|c|}{ Pair $(n=35)$} \\
\hline & Estimate & Std. error & Estimate & Std. error & Estimate & Std. error \\
\hline Intercept & 12.622 & - & 19.455 & - & 37.937 & - \\
\hline Animal (or pair) entry weight & -0.014 & 0.019 & -0.006 & 0.010 & -0.020 & 0.019 \\
\hline Apr-Jun precipitation & 0.001 & 0.004 & 0.000 & 0.001 & 0.001 & 0.005 \\
\hline Apr-Jun avg. temperature & -0.001 & 0.179 & -0.005 & 0.070 & -0.003 & 0.241 \\
\hline (Apr-Jun precipitation $) \times($ Apr-Jun avg. temperature $)$ & 0.001 & 0.004 & 0.002 & 0.002 & 0.002 & 0.006 \\
\hline Jul-Sep precipitation & 0.001 & 0.006 & 0.001 & 0.002 & 0.002 & 0.008 \\
\hline Jul-Sep avg. temperature & 0.079 & 0.209 & 0.018 & 0.064 & 0.088 & 0.251 \\
\hline (Jul-Sep precipitation) $\times($ Jul-Sep avg. temperature) & -0.001 & 0.004 & 0.000 & 0.001 & -0.001 & 0.005 \\
\hline Prior Apr-Sep precipitation & 0.002 & 0.005 & 0.000 & 0.001 & 0.002 & 0.005 \\
\hline Prior Oct-Mar precipitation & 0.005 & 0.010 & 0.003 & 0.004 & 0.008 & 0.013 \\
\hline Coefficient of determination $\left(R^{2}\right)$ & 0.44 & & 0.55 & & 0.47 & \\
\hline
\end{tabular}

estimates (Table 4), indicating that their beef production was largely uninfluenced by weather parameters. Hybrid vigor (Cartwright, 1970) and larger body size (Cartwright, 1979) of these crossbred cows may result in higher milk production than Herefords, which may aid in diminishing the seasonal weather influences. This idea is also supported in that both Angus and Charolais breeds have been shown to produce more milk than Herefords (Melton et al., 1967). Optimizing milk producing genetics increases calf growth (Clutter and Nielsen, 1987), so the crossbreds perhaps had a genetic advantage over the Herefords. Reduced statistical power (and therefore ability to detect weather effects) due to fewer years in the grazing experiment for the crossbreds may have also contributed to these results, however.

One unexpected result was that prior winter (OctoberMarch) precipitation showed relatively large positive effect sizes for the Herefords (compared to other precipitation effect sizes) that were also robust to the standard errors (Table 3). Greater snow increases soil moisture levels in northern mixed-grass prairie, especially at deeper soil depths. This may increase water availability to perennial plants throughout the entire growing season (Chimner and Welker, 2005). As such, increased forage production resulting from greater winter precipitation could clearly benefit cow-calf production.

As expected, spring (April-June) precipitation influenced Hereford cow-calf production. Forage production in this northern mixed-grass prairie is increased by greater spring precipitation (Derner and Hart, 2007), as is corresponding yearling steer production (Derner et al., 2008; Reeves et al., in press). Our results clearly indicate that seasonal precipitation, both winter and spring, influences cow-calf production in northern mixed-grass prairie. Overall, our livestock-weather model was able to explain up to $66 \%$ of the variation in the Hereford beef production (Table 3). Because stocking rates influence cow-calf production (e.g., Gillen and Sims, 2002; Kothmann et al., 1971 ), stocking rate changes across years may have played a substantive role in explaining the remaining $\geq 34 \%$ of variation in the model results in Table 3 . It should be noted here, however, that initial modeling efforts eliminating the highest and lowest stocking rate years for the Herefords resulted in no discernible weather patterns being found, perhaps due to reduced statistical power. Similarly, including stocking rate as a covariate in initial models showed stocking rate to be a large determinant of beef production, which washed out all weather effects. Regardless of the somewhat variable Hereford stocking rates across the study period, interesting and meaningful patterns were still observed in the model-averaged weather parameters. Thus, it can be said that seasonal weather patterns can influence Hereford cow-calf production in northern mixed-grass prairie.

Results here and from Reeves et al. (in press) demonstrate that multiple factors such as cattle breed, type (i.e., cow, calf, steer, etc.), stocking rate, and plant community composition can alter the effects of seasonal weather patterns on beef production from northern mixed-grass prairie. Likewise, cooler growing seasons increased Hereford calf weight gains in a more $\mathrm{C}_{3}$-dominated mixed-grass prairie in Montana (MacNeil and Vermeire, 2012), whereas no robust seasonal temperature effects were detected for Hereford cow-calf production in this study where the plant community has a lower composition of $C_{3}$ grasses. Because of the complexity of factors influencing beef production in northern mixed-grass prairie, emphasis is needed on improving decision support tools for ranching operations to enhance site-specific decision making (Derner et al., 2012).

Enhancing decision support tools such as GPFARM (Andales et al., 2005, 2006; Shaffer et al., 2000) with our findings will assist ranchers in predicting beef production prior to the grazing season in response to forecasted seasonal temperature and precipitation. This would facilitate optimizing marketing strategies and minimizing enterprise risk. Integrating readily available seasonal temperature and precipitation forecasts such as the threemonth weather outlooks from NOAA facilitates the widespread applicability of these beef production estimates to site-specific management (Derner et al., 2012). The parsimonious model structure used also helps to maximize the utility of these data for decision support tools by requiring ranchers to acquire only six weather parameters 
(i.e., seasonal forecasts or actual data for prior growing season and winter precipitation) that are all web-based, free, and easily accessible from NOAA.

\section{Conclusion}

Long-term cow-calf beef production datasets from rangelands are rare, and as such, are quite valuable for determining the influences of seasonal weather patterns on livestock production. We used over 30 yrs of data from Wyoming, USA, to show that Hereford cow-calf pairs are more sensitive to seasonal weather variability than Red Angus $\times$ Charolais $\times$ Salers crossbreds. Wet spring conditions, along with wet prior winters, increased Hereford cow, calf, and pair beef production under moderate stocking rates. Building these data into decision support tools (that would ideally be developed in a user-friendly manner for use on personal computers or mobile devices) will assist ranchers in making better informed enterprise-level decisions based upon expected seasonal weather conditions. This will hopefully lead to increased beef production efficiency, which will become increasingly important in coming decades as the human population, and corresponding food demand, grows.

\section{Conflict of interest}

There are no conflicts of interest to report for this manuscript.

\section{Acknowledgments}

We thank multiple ARS technicians, especially Matt Mortensen, Pam Freeman, and Stanley Clapp, for their assistance in gathering and compiling data for these analyses. Numerous student workers from over the years are thanked as well. We are especially grateful to Richard (Dick) H. Hart for initiating this study, as well as the University of Wyoming and 8A Hay and Cattle Company for providing the study animals.

\section{References}

Ames, D., 1980. Thermal environment affects production efficiency of livestock. BioScience 30, 457-460.

Andales, A.A., Derner, J.D., Bartling, P.N.S., Ahuja, L.R., Dunn, G.H., Hart, R.H., Hanson, J.D., 2005. Evaluation of GPFARM for simulation of forage production and cow-calf weights. Rangeland Ecol. Manage. 58, 247-255.

Andales, A.A., Derner, J.D., Ahuja, L.R., Hart, R.H., 2006. Strategic and tactical prediction of forage production in northern mixed-grass prairie. Rangeland Ecol. Manage. 59, 576-584

Anderson, D.R., Burnham, K.P., Thompson, W.L., 2000. Null hypothesis testing: problems, prevalence, and alternative. J. Wildlife Manage. 64, 912-923.

Anderson, D.R., Burnham, K.P., Gould, W.R., Cherry, S., 2001. Concerns about finding effects that are actually spurious. Wildlife Soc. Bull. 29 311-316.

Briske, D.D., Derner, J.D., Milchunas, D.G., Tate, K.W., 2011. An evidencebased assessment of prescribed grazing practices. In: Briske, D.D (Ed.), Conservation Benefits of Rangeland Practices: Assessment, Recommendations, and Knowledge Gaps, United States Department of Agriculture, Natural Resources Conservation Service, pp. 21-74.

Burnham, K.P., Anderson, D.R., 2004. Multimodal inference-understanding AIC and BIC in model selection. Sociol. Methods Res. 33, 261-304.
Cartwright, T.C., 1970. Selection criteria for beef cattle for the future. J. Anim. Sci. 30, 706-711.

Cartwright, T.C., 1979. Size as a component of beef production efficiency: cow-calf production. J. Anim. Sci. 48, 974-980.

Chigaru, P.R.N., Topps, J.H., 1981. The composition of body-weight changes in underfed lactating beef cows. Anim. Prod. 32, 95-103.

Chimner, R.A., Welker, J.M., 2005. Ecosystem respiration responses to experimental manipulations of winter and summer precipitation in a mixedgrass prairie, WY, USA. Biogeochemistry 73, 257-270.

Clutter, A.C., Nielsen, M.K., 1987. Effect of level of beef cow milk production on pre-and postweaning calf growth. J. Anim. Sci. 64, 1313-1322.

Corah, L.R., Dunn, T.G., Kaltenbach, C.C., 1975. Influence of prepartum nutrition on the reproductive performance of beef females and the performance of their progeny. J. Anim. Sci. 41, 819-824.

Davis, K.C., Tess, M.W., Kress, D.D., Doornbos, D.E., Anderson, D.C., 1994. Life cycle evaluation of five biological types of beef cattle in a cowcalf range production system: II. Biological and economic performance. J. Anim. Sci. 72, 2591-2598.

Derner, J.D., Hart, R.H., 2007. Grazing-induced modifications to peak standing crop in northern mixed-grass prairie. Rangeland Ecol. Manage. 60, 270-276.

Derner, J.D., Hart, R.H., Smith, M.A., Waggoner, J.W., 2008. Long-term cattle gain responses to stocking rate and grazing systems in northern mixed-grass prairie. Livest. Sci. 117, 60-69.

Derner, J.D., Augustine, D.J., Ascough II, J.C., Ahuja, L.R., 2012. Opportunities for increasing utility of models for rangeland management. Rangeland Ecol. Manage. 65, 623-631.

Dochtermann, N.A., Jenkins, S.H., 2011. Developing multiple hypotheses in behavioral ecology. Behav. Ecol. Sociobiol. 65, 37-45.

Food and Agriculture Organization of the United Nations (FAO), 2011. The State of the World's Land and Water Resources for Food and Agriculture. Rome, Italy.

Gillen, R.J., Sims, P.L., 2002. Stocking rate and cow-calf production in sagebrush rangeland. J. Range Manage. 55, 542-550.

Grings, E.E., Short, R.E., MacNeil, M.D., Haferkamp, M.R., Adams, D.C. 1996. Efficiency of production in cattle of two growth potentials on northern Great Plains rangelands during spring-summer grazing. J Anim. Sci. 74, 2317-2326.

Grings, E.E., Short, R.E., Klement, K.D., Geary, T.W., MacNeil, M.D., Haferkamp, M.R, Heitschmidt, R.K., 2005. Calving system and weaning age effects on cow and preweaning calf performance in the Northern Great Plains. J. Anim. Sci. 83, 2671-2683.

Hanson, J.D., Baker, B.B., Bourdon, R.M., 1993. Comparison of the effects of different climate change scenarios on rangeland livestock production. Agric. Syst. 41, 487-502.

Hart, R.H., Waggoner Jr., J.W., Dunn, T.G., Kaltenback, C.C., Adams, L.D., 1988. Optimal stocking rate for cow-calf enterprises on native range and complementary improved pastures. J. Range Manage. 41, 435-441.

Holechek, J.L., Pieper, R.D., Herbel, C.H., 1998. Range Management: Principles and Practices, third ed. Prentice-Hall, Upper Saddle River, New Jersey, USA.

Houghton, P.L., Lemenager, R.P., Horstman, L.A., Hendrix, K.S., Moss, G.E. 1990. Effects of body composition, pre- and postpartum energy level, and early weaning on reproductive performance of beef cows and preweaning calf gain. J. Anim. Sci. 68, 1438-1446.

Johnson, H.D., 1965. Environmental temperature and lactation (with special reference to cattle). Int. J. Biometeorol. 9, 103-116.

Kachergis, E., Derner, J., Roche, L., Tate, K., Lubell, M., Mealor, R., Magagna, J., 2013. Characterizing Wyoming ranching operations: natural resource goals, management practices, and information sources. Nat. Resour. 4, 45-54.

Kothmann, M.M., Mathis, G.W., Waldrip, WM.J., 1971. Cow-calf response to stocking rates and grazing systems on native range. J. Range Manage. 24, 100-105.

MacNeil, M.D., Vermeire, L.T, 2012. Effect of weather patterns on preweaning growth of beef calves production in the Northern Great Plains. Agric. Syst. 3, 929-935.

Mader, T.L., Frank, K.L., Harrington, J.A., Hahn, G.L., Nienaber, J.A., 2009. Potential climate change effects on warm-season livestock production in the Great Plains. Clim. Change 97, 529-541.

Manley, W.A., Hart, R.H., Samuel, M.J., Smith, M.A., Waggoner, J.W., Manley, J.T., 1997. Vegetation, cattle, and economic responses to grazing strategies and pressures. J. Range Manage. 50, 638-646.

Melton, A.A., Riggs, J.K., Nelson, L.A., Cartwright, T.C., 1967. Milk production, composition and calf gains of Angus, Charolais, and Hereford cows. J. Anim. Sci. 26, 804-809. 
Oesterheld, M., Loreti, J., Semmartin, M., Sala, O.E., 2001. Inter-annual production of a semi-arid grassland related to previous-year production. J. Veg. Sci. 12, 137-142.

Patterson, H.H., Whittier, J.C., Rittenhouse, L.R., Schutz, D.N., 1999. Performance of beef cows receiving cull beans, sunflower meal, and canola meal as protein supplements while grazing native winter range in Eastern Colorado. J. Anim. Sci. 77, 750-755.

Reeves, J.L., Derner, J.D., Sanderson, M.A., Petersen, M.K., Vermeire, L.T., Hendrickson, J.R., Kronberg, S.L. Temperature and precipitation affect steer weight gains differentially by stocking rate in northern mixedgrass prairie. Rangeland Ecol. Manage., http://dx.doi.org/10.2111/ REM-D-12-00157.1, in press.

Ritten, J.P., Frasier, W.M., Bastian, C.T., Gray, S.T., 2010. Optimal rangeland stocking decisions under stochastic and climate-impacted weather. Am. J. Agric. Econ. 92, 1242-1255.

Sage, R.F., Kubien, D.S., 2007. The temperature response of $C_{3}$ and $C_{4}$ photosynthesis. Plant Cell Environ. 30, 1086-1106.

SAS Institute Inc., 2012. JMP ${ }^{\mathbb{R}} 10$ Modeling and Multivariate Methods. SAS Institute Inc. Cary, NC.
Shaffer, M.J., Bartling, P.N.S., Ascough II, J.C., 2000. Object-oriented simulation of integrated whole farms: GPFARM framework. Comput. Electron. Agric. 28, 29-49.

Stevenson, A., Baumgartner, R.E., Schuman, G.E., 1984. High Plains Grasslands Research Station Detailed Soil Survey. USDA-ARS,Wyoming Agricultural Experiment Station, USDA-SCS. USDA Publication 1-84/ $1 \mathrm{C} / 3.62$.

Stromberg, B.E., Vatthauer, R.J., Schlotthauer, J.C., Myers, G.H., Haggard, D. L., King, V.L., Hanke, H., 1997. Production responses following strategies parasite control in a beef cow/calf herd. Vet. Parasitol. 68, 315-322.

Torell, L.A., Murugan, S., Ramirez, O.A., 2010. Economics of flexible versus conservative stocking rates to manage climate variability risk. Rangeland Ecol. Manage. 63, 415-425.

Wang, H., Zhang, X., Zou, G., 2009. Frequentist model averaging estimation: a review. J. Syst. Sci. Complexity 2009, 732-748.

Williams III, G.J., 1974. Photosynthetic adaptation to temperature in $C_{3}$ and $\mathrm{C}_{4}$ grasses-a possible ecological role in the shortgrass prairie. Plant Physiol. 54, 709-711. 